\title{
Obituaries
}

Obituaries should be submitted by email to Jadene Doak at jadene.doak@springernature.com

All submitted obituaries should be 400 words maximum in length (apart from obituaries for past presidents of the BDA where the length should be 800 words).

Content of the obituary is down to the individual author, and the approval of the family should be given for the obituary prior to submission to the BDJ.

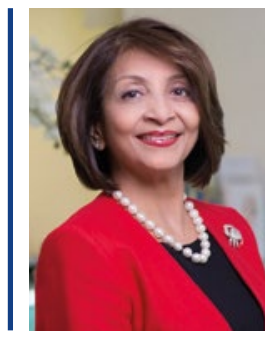

\section{Rashmi Patel MBE}

$1952-2020$

It is with profound sadness that we announce the untimely passing of Dr Rashmi Patel MBE on 25 October 2020 after a long illness.

Having obtained her qualification in 1977, Rashmi set up a practice along with her husband Mahesh in Edmonton. She continued her postgraduate studies with vigour. Having obtained her MFGDP, she went on to teach and examine Dental Nurses and MFGDP candidates.

Rashmi was a proactive member in several dental and other societies. She was a regular attendee at ADI, BDA, FGDP and many other dental events. She was instrumental in founding, guiding and developing the AOG (now also known as Dental Link) to a membership base which became the third largest society in the UK. Her elegant demeanour coupled with her dynamic character and enthusiasm left an indelible mark on all that met her.

Rashmi served on the Standing Dental Advisory Committee to the Secretary of State for Health during the early 2000s. She was raised to the Most Excellent Order of the British Empire as a Member (MBE) in 2003 for her extensive contributions to the dental profession and charities. She was elected an Honorary Fellow of the Pierre Fauchard Academy. She was also awarded the highest Life Time Achievement Award from Dental Link in 2019 as the longest-serving active committee member of the society.

In the late 1980s, Rashmi set up her own practice in Hampstead which attracted many specialists as her associate dentists and top-quality support staff. She was an early adopter, amongst other things, in terms of décor and quality of practice presentation. She was a pioneer in using a professional design company for her Hampstead practice and created one of the most beautifully presented practices at the time. In the early 1980s, her practice featured in the British Dental Trade Associations video 'The Way Ahead' when using professional dental designers was just making a mark.

In addition to setting up a series of successful practices, she had time to raise her beloved children Anita and Neil. She passed on her values of education couched with kindness. Today, they are both well-rounded dentists in their own right with their own practices. The family has grown with gorgeous grandchildren Dylan and Sophia, who she adored and loved. We will all miss Rashmi. Dr Manny Vasant MBE

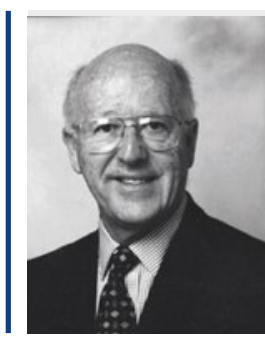

\section{Edward Samuel Broadway OBE}

$1927-2020$

Eddie, the elder of twins, was born in Hackney, his early education was at Bancroft's School and his undergraduate years were spent at The Royal Dental Hospital, where he qualified BDS with Honours. After House Surgeon appointments and during RAF National Service, he gained FDS RCS. On demobilisation he worked at the Westminster, St Thomas's, Eastman and Royal Dental Hospitals and passed the D Orth RCS.

In 1957, he was appointed the first Consultant Orthodontist to the East Anglian region, based in Ipswich. He set up clinics, and as a member of the Hospitals Group (President 1974) lectured to BDA sections. This progressed and became normalised under the Regional Postgraduate Medical and Dental Federation. Cambridge University appointed him Regional Advisor; he subsequently became its Chairman and latterly dental Dean.

He was a council member of the British Society for the Study of Orthodontics and a founder member of the Consultant Orthodontists Group.

A WHO fellowship enabled him to visit Scandinavia with his plastic surgical colleague to further his interest in cleft lip and palate repair. He joined the European Orthodontic Society and was an active participant.

In the 1970s, a new hospital was being planned for Ipswich; as planning committee chairman, he negotiated with the Minister of Health for a nucleus hospital, and in 1977, he was awarded a Queen's Jubliee Medal.

From 1978, he served on the East Anglian Regional Health Authority, and in 1984 was elected Vice Chairman. He gained experience of government's attitudes to medicine and dentistry. In 1990, he was appointed OBE for Services to Medicine and on retirement he was awarded BDA life membership.

His dental training helped him to become a skilled craftsman. He built two Mirror dinghies in which he taught his children to sail. Before retirement, he started working as a silversmith, becoming accomplished and accepted into the Suffolk Craft Society, selling his products in East Anglian Galleries.

He was married to Jill for 65 years and had three children, two of whom became doctors. His later years were marred by spinal arthritis which was a great handicap. Unfortunately, latterly, Jill suffered from loss of short-term memory and he became her devoted carer until he broke his hip and died from postoperative COVID-19 pneumonia. Jill sadly died aged 93 from old age on 23 September.

Their joint funeral was at Ipswich Crematorium on 30 October 2020.

Ronald Broadway 